\title{
UJI BIOAKTIVITAS FORBAZOL E TERHADAP HAMBATAN PERTUMBUHAN PADA STAPHYLOCOCCUS AUREUS
}

\author{
Ni Putu Ristiati \\ Jurusan Pendidikan Biologi, FMIPA Undiksha Singaraja, \\ Singaraja Indonesia
}

email: puturistiati@gmail.com

\begin{abstract}
Abstrak
Forbazol E dapat disintesis dari 1-(p-tosil) pirol-2-karbonil klorida dan fenasil amonium klorida dengan rendeman cukup tinggi melalui empat tahap reaksi yaitu : pertama, reaksi penggabungan; kedua, siklodehidrasi; ketiga,hidrolisis; dan keempat, klorinasi. Staphylococcus aureus merupakan bakteri gram positif. Untuk itu perlu diteliti : (a) forbazol $\mathrm{E}$ dapat menghambat pertumbuhan $\mathrm{S}$. aureus ; (b)konsentrasi forbazol E $75 \mathrm{mg} / \mathrm{L}$ akan menimbulkan hambatan pertumbuhan $S$. aureus lebih tinggi dari konsentrasi $37,5 \mathrm{mg} / \mathrm{L}$.Penelitian eksperimental ini menggunakan rancangan the randomized-posttest-only control group design dan melibatkan 9 sampel pada kelompok kontrol, 9 sampel pada kelompok perlakuan I dan 9 sampel pada perlakuan II. Data yang diperoleh dianalisis dengan menggunakan uji anova pada taraf signifikansi $5 \%$. Hasil penelitian membuktikan forbazol $E$ dapat menghambat pertumbuhan, pemberian forbazol $E$ pada pada kelompok perlakuan II dengan konsentrasi $75 \mathrm{mg} / \mathrm{L}$ menimbulkan hambatan pertumbuhan $S$. aureus lebih tinggi dibandingkan dengan kelompok perlakuan I dengan konsentrasi $37,5 \mathrm{mg} / \mathrm{L}(\mathrm{p}<0,05)$, uji lanjutan dengan uji beda nyata terkecil (BNT) pada taraf signifikansi 5\% diperoleh bahwa hambatan pertumbuhan $S$. aureus pada kelompok perlakuan II $(75 \mathrm{mg} / \mathrm{L})$ berbeda bermakna dengan kelompok perlakuan I $(37,5 \mathrm{mg} / \mathrm{L})(\mathrm{p}<0,05)$. Bertolak dari pembahasan di atas dapat disimpulkan bahwa bioaktivitas forbazol $E$ dapat menghambat pertumbuhan $S$. aureus.
\end{abstract}

Kata kunci: bioaktivitas, forbazol E, hambatan pertumbuhan, Staphylococcus aureus.

\begin{abstract}
Phorbazole E can be synthetized from 1-(p-tosil) pyrrole-2-carbonyl chloride and phenacyl ammonium chloride with a high yield content through four reaction phases, i.e.,first, coupling reaction; second, cyclodehydration; third, hydrolysis; and fourth, chlorination. Staphylococcus aureus is a positive gram bacterium. Thus a study needs to be conducted on (a) phorbazole $\mathrm{E}$ bioactivity can retard the growth of $S$. aureus(b) whether an application of a $75 \mathrm{mg} / \mathrm{L}$ phorbazole $E$ concentration will cause retard the growth higher than that of a $37.5 \mathrm{mg} / \mathrm{L}$ phorbazole $\mathrm{E}$ concentration to $S$. aureus. This experimental study used the randomized postestonly control group design that involved 9 samples of the control group, 9 samples of the treatment I group and 9 samples of the treatment II group. The obtained data were analyzed using the anova test at the $5 \%$ level of significance. The result proves that phorbazole $\mathrm{E}$ can retard the growth of $S$. aureus, the application of
\end{abstract}


phorbazole $\mathrm{E}$ at the treatment II group with a $75 \mathrm{mg} / \mathrm{L}$ concentration caused a higher degree of retardation to S.aureus than that of the treatment I group with a $37.5 \mathrm{mg} / \mathrm{L}(\mathrm{p}<0.05)$, a further of the least significance difference test at the $5 \%$ level of significance shows that the retardation to the growth of $S$. aureus at the treatment II group $75 \mathrm{mg} / \mathrm{L}$ ) differed significantly from that of treatment I group $(37.5 \mathrm{mg} / \mathrm{L})$. In view of the discussion above it can be concluded that phorbazole $\mathrm{E}$ bioactivity can retard the growth of S.aureus.

Keywords: bioactivity, phorbazole E, growth retardation, and Staphylococcus aureus.

\section{PENDAHULUAN}

Forbazol A, B, C dan D yang diisolasi dari bunga karanglndo-Pasifik Phorba clathrata, telah teridentifikasi strukturnya dan diketahui sebagai turunan oksazol baru yang mengandung unit fenilpiroliloksazol terklorinasi, karena itu dinyatakan sebagai alkaloid yang berasal dari laut (Rudi dkk.,1994). Alkaloid merupakan senyawa yang mempunyai satu atau lebih atom dalam sistem cincin heterosiklik, yang menginduksi secara nyata aktivitas fisiologis pada hewan dan manusia (Holde, 2000; Murray dkk., 2003). Keempat forbazol ini mengandung kerangka dasar yang sama, hanya berbeda satu sama lainnya dalam substitusi atom klor sepanjang kerangka dasar tersebut. Keempat senyawa yang diekstrak dari Phorbas clathrata dengan pelarut etil asetat kemudian satu sama lainnya dipisahkan dengan kromatografi flash vakum dan kolom sphadex LH-20. Dari ekstrak etil asetatnya diperoleh randemen forbazol $A, B, C, D$ masingmasing 2,5\%, 0,25\%, 0,025\% dan $0,01 \%$ (Rudi dkk.,1994). Menurut Radspieler (2000) sintesis forbazol C dilakukan dengan $p$ hydroxybenzaldehyde dan 2methylpyrrol-5-ethylcarboxylate. Cincin oksazol dibentuk melalui siklodehidrasi.
Penelitian pendahuluan (Adamczeski dkk.,1988) menunjukkan bahwa forbazol memiliki efek imunomodulatori. Menurut Baratawidjaja (2001) imunomodulator merupakan obat-obatan yang dapat mengembalikan ketidakseimbangan sistem imun. Kadar forbazol yang sangat sedikit dan menunjukkan sifat aktivitas biologis maka perlu usaha untuk mensintesisnya di laboratorium sehingga tersedia dalam jumlah yang cukup untuk keperluan penelitian tentang uji bioaktifitas.

Forbazol $E$ dapat disintesis dari 1-(p-tosil) pirol-2-karbonil klorida dan garam fenasil amonium klorida dengan rendemen cukup tinggi melalui empat tahap reaksi yaitu: pertama, reaksi penggabungan (coupling); kedua, siklodehidrasi (cyclodehydration); ketiga, hidrolisis (hydrolysis); dan keempat, klorinasi. Dari sintesis ini berhasil diperoleh forbazolE dengan rendemen 26,3\% (Muderawan, 2003).

Stafilokokus patogen sering dapat menghemolisis sel darah dan mengkoagulasi plasma diantaranya Staphylococcus aureus yang merupakan bakteri gram positif. Beberapa di antara stafilokokus tergolong flora normal kulit dan selaput lendir manusia. Stafilokokus cepat menjadi resisten terhadap banyak zat 
anti mikroba dan menyebabkan proses pengobatan yang sulit (Jawetz dkk., 2004).

Cara kerja senyawa bioaktif antimikroba menurut Brock (2003) adalah: (1) menghambat pembentukan dinding sel misalnya antibiotika sikloserin, vancomisin, basitrasin, penisilin, sephalosporin, monobaktam, karbapenem; (2) menghambat metabolisme asam folat misalnya trimetoprim, sulfonamid; (3) menghambat sintesis protein pada subunit 50Smisalnya kloramfenikol, eritromisin/makrolida, klindamisin, linkomisin, sedang yang menghambat sintesis protein subunit $30 \mathrm{~S}$ misalnya tetrasiklin, spektinomisin, streptomisin, gentamisin, tobramisin, kanamisin/aminoglikosida, amikasin, nitrofuran; (4) menghambat kerja enzim polimerase RNA (pada DNA) misalnya rifampin; dan (5) menghambat kerja enzim DNA girase misalnya novobiosin, asam nalidiksik, norflosaksin (kuinolon). Menurut Walsh (2000) ada tiga sasaran obat antibakteri, yaitu : (1) menghambat biosintesis dinding sel; (2) menghambat sintesis protein bakteri; dan (3) menghambat replikasi dan perbaikan DNA bakteri.

Berdasarkan latar belakang masalah di atas, rumusan masalah penelitian adalah: (1) Apakah forbazol E menghambat pertumbuhan Staphylococcus aureus ? (2) Berapakah konsentrasi optimum forbazol $\mathrm{E}$ dalam menghambatpertumbuhan

Staphylococcus aureus? Tujuan yang ingin dicapai pada penelitian ini adalah sebagai berikut: (1) Untuk membuktikan bahwa forbazol $E$ menghambat pertumbuhan S.aureus (2) Untuk mengetahui konsentrasi optimum forbazol $E$ menghambat pertumbuhan S.aureus. Manfaat yang diharapkan dari hasil penelitian ini adalah sebagai berikut:Penelitian ini dapat memperkaya alternatif penggunaan sumber daya alam hayati kelautan sebagai senyawa bahan alam aktif yang dapat digunakan sebagai obat yang efektif untuk menyembuhkan penyakit. Forbazol $\mathrm{E}$ yang mampu menghambat pertumbuhan Staphylococcus aureus, dapat dimanfaatkan untuk menanggulangi penyakit yang disebabkan oleh stafilokokus pada manusia antara lain seperti : keracunan makanan, bisul, toxic-schock syndrome.

\section{METODE}

Rancangan dalam penelitian ini merupakan eksperimen sungguhan (True experimental). Dikatakan eksperimen sungguhan karena memenuhi tiga prinsip pokok seperti replikasi, randomisasi, dan adanya kontrol atau perlakuan banding (Bakta, 1997). Rancangan penelitian eksperimen yang digunakan adalah : The Randomized Posttest- Only Control Group Design (Zaenuddin, 1994, Bawa, 2000). Populasi yang digunakan dalam penelitian ini adalah bakteri S.aureus ATTC 25922 hasil isolasi kultur murni dari laboratorium mikrobiologi FK UNUD Denpasar. Sampelmerupakan bagian dari atau cuplikan dari suatu populasi (Sujana,1994). Jadi sampel dalam penelitian ini adalah bakteri S.aureus yang diambil dari kultur cair. Perlakuan dalam penelitian ini yaitu forbazol $E$ dengan konsentrasi $37,5 \mathrm{mg} / \mathrm{L}$ dan 75 $\mathrm{mg} / \mathrm{L}$. Karena bakteri sudah distandar dengan McFarland 0,5 jumlah bakteri/sampel bakteri sudah sama. Jumlah ulangan 9 kali berdasarkan (T- 
1)(R-1) $\geq 15$ (Rochiman, 1989) dimana $\mathrm{T}=$ perlakuan dan $\mathrm{R}=$ replikasi. Jadi , unit percobaan akan berjumlah 9 tabung reaksi yang berisi medium Mueller Hinton cair untuk menumbuhkan S.aureus.Jumlah seluruh unit percobaan menjadi 27 unit.

ForbazolE adalah senyawa bioaktif hasil sintesis di laboratorium (Muderawan, 2003). Konsentrasi yang digunakan $75 \mathrm{mgr} / \mathrm{L}$ dan 37,5 $\mathrm{mg} / \mathrm{L}$. Hambatan pertumbuhan $S$. aureus adalah hambatan pertumbuhan sel yang dapat diukurdengan spektrofotometer. Pengukuran ini didasarkan atas asumsi bahwa apabila sinar diarahkan kepada suspensi sel bakteri maka jumlah sel bakteri didalam suspensi berbanding lurus dengan jumlah cahaya yang dihamburkan, atau berbanding terbalik dengan jumlah cahaya yang diteruskan (Benson, 2002, Phillips, 1991). Ukuran kekeruhan dinyatakan dengan nilai O.D (optical density).Suhu $37^{\circ} \mathrm{C}$ untuk pertumbuhan S.aures dalam inkubator.pH optimum : 6,4 untuk pertumbuhan S.aures. Medium pertumbuhan S.aures digunakan media Mueller Hinton broth (Oxoid). Strain yang digunakan S.aures AATC 25922 dari FK-UNUD.

Alat penelitianLaminar air flow, incubator, centrifuge, spectrofotometer, pH meter, autoklav, cawan petri, tabung reaksi, labu erlemeyer, pipet, gelas ukur, gelas kimia, kawat inokulasi berkolong, batang pengaduk, timbangan, kompor, lampu spiritus, pinset. Cara pengukuranpertumbuhan S.aureus digunakan spectrofotometer (A600).Bahan PenelitianForbazol E yang digunakan dalam penelitian ini merupakan hasil sintesis di laboratorium (Muderawan, 2003). Medium yang digunakan untuk pertumbuhan adalah Mueller HintonBroth yang dikeluarkan oleh Oxoid, formulanya terdiri dari :beef, dehydrated infusion from 3000,0, casein hydrolysate 17,5, starch 1,5, agar 17,0.Suhu inkubator dalam penelitian ini adalah $37^{\circ} \mathrm{C} . \mathrm{pH}$ yang optimal $(6,4)$ untuk pertumbuhan S.aures.Isolat S.aureus yang diperoleh dari Bagian mikrobiologi FK-UNUD.Alkohol,aquades steril, spiritus, cotton swabs, kertas saring, kapas. Dianalisis denganUji Kolmogorov-Smirnov untuk normalitas data.Uji Levene untuk homogenitas data.Uji t untuk beda rerata masingmasing kelompok.Uji anava satu arah untuk beda rerata antar kelompok.Uji perbandingan ganda (multiple comparison: Post Hock) antar kelompok untuk menguji kelompok mana yang berbeda dengan kelompok yang mana, dengan menggunakan uji LSD (untuk data yang variannya homogen).Dalam percobaan ini digunakan tingkat kemaknaan $\alpha=0,05$

\section{HASIL DAN PEMBAHASAN}

Hambatan pertumbuhan yang didata pada penelitian ini adalah hambatan pertumbuhan sel S.aureus yang diukur dengan spectrofotometer dengan absorbancepadaO.D 600nm. Diperlukan penghitungan jumlah sel mikroba untuk membuat kurva pertumbuhan.Metode yang digunakan dalam penelitian ini adalah pengukuran secara turbidometri. Pengukuran turbidometri digunakan untuk mengetahui jumlah biomassa sel total dalam suspensi dengan mengukur kerapatan cahaya atau densitas optik kultur kaldu dengan spektrofotometer, dengan alat ini turbiditas dinyatakan dalam unit absorbance atau daya serap. 
Bagi organisme uniselular, absorbance adalah proporsi jumlah sel maupun berat sel. Turbiditas dapat dibaca pada alat ini sehingga digunakan sebagai pengganti untuk menghitung koloni bakteri. Teknik turbidometri secara khusus digunakan untuk menentukan massa sel selama pertumbuhan, sebagai evaluasi terhadap efek zat antibakteri terhadap bakteri.

Distribusi data pada nilai daya serap cahaya berdistribusi normal, maka dilakukan analisis parametrik dengan menggunakan uji anava satu arah pada taraf signifikansi $5 \%$. Hasil analisis data hambatan pertumbuhan menunjukkan bahwa rerata nilai kerapatan cahaya pada kelompok kontrol, perlakuan I dan perlakuan II adalah berbeda bermakna. Dikatakan demikian karena nilai $p<0,05$. Hasilanalisis data hambatan pertumbuhan dapat dilihat pada tabel 1 .

Tabel 1.Data pertumbuhan S.aureus pada media Mueller Hinton cair yang diberi perlakuan forbazol E berdasarkan daya serap cahaya

\begin{tabular}{lccc}
\hline Kelompok & $\begin{array}{c}\text { Nilai daya serap cahaya* } \\
\text { Rerata } \pm \text { Simpang baku }\end{array}$ & Nilai F & Nilai $p$ \\
\hline 1. Kontrol & $1,357 \pm 0,492$ & 338,862 & 0,000 \\
2. Forbazol E $37,5 \mathrm{mg} / \mathrm{L}$ & $0,325 \pm 0,002$ & & \\
3. Forbazol E $75 \mathrm{mg} / \mathrm{L}$ & $0,207 \pm 0,109$ & & \\
\hline
\end{tabular}

* O.D = 600nm

Data di atas menunjukkan bahwa rerata nilai daya serap (O.D 600 $\mathrm{nm})$ pada kelompok kontrol, perlakuan I (forbazol E 37,5 mg/L) dan perlakuan II (forbazol E $75 \mathrm{mg} / \mathrm{L}$ ) adalah berbeda bermakna. Dikatakan demikian karena semua nilai $p<0,05$ atau dengan kata lain dapat dikatakan bahwa : (a) rerata nilai daya serap cahaya $(O . D=600 \mathrm{~nm})$ pada kelompok kontrol $(1,357)$ berbeda bermakna dengan rerata nilai daya serap cahaya pada kelompok perlakuan I $(0,325)$; (b) rerata nilai daya serap cahaya $(O . D=600 \mathrm{~nm})$ pada kelompok kontrol $(1,357)$ berbeda bermakna dengan rerata nilai daya serap cahaya pada kelompok perlakuan II $(0,207)$; (c) rerata nilai daya serap cahaya (O.D = $600 \mathrm{~nm})$ pada kelompok perlakuan I $(0,325)$ berbeda bermakna dengan rerata nilai daya serap cahaya pada kelompok perlakuan II $(0,207)$.

Analisis hasil pengukuran nilai daya serap cahaya pada O.D $=600 \mathrm{~nm}$ dengan spektrofotometer mulai dari 0 jam sampai dengan 28 jam, dapat dilihat pada tabel 2. 
Tabel2 Data pertumbuhan S.aureus pada media Mueller Hinton cair yang diberi perlakuan forbazol E antara $0-28$ jam waktu inkubasi

\begin{tabular}{cccccc} 
Waktu & $\begin{array}{c}\text { Nilai daya * } \\
\text { serap cahaya } \\
\text { Kontrol }\end{array}$ & $\begin{array}{c}\text { Nilai } \\
\text { Fam) } \\
\text { Forbazol E } \\
\text { Re,5 mg/L } \\
\text { Rerata } \pm \text { SB }\end{array}$ & $\begin{array}{c}\text { Norbazol E } \\
75 \mathrm{mg} / \mathrm{L} \\
\text { Rerata } \pm \text { SB }\end{array}$ & $\mathrm{F}$ & $\mathrm{p}$ \\
\hline 0 & $0,211 \pm 0,017$ & $0,303 \pm 0,016$ & $0,214 \pm 0,022$ & 69,580 & 0,000 \\
4 & $0,979 \pm 0,031$ & $0,339 \pm 0,008$ & $0,174 \pm 0,036$ & 2113,236 & 0,000 \\
8 & $1,414 \pm 0,059$ & $0,323 \pm 0,011$ & $0,212 \pm 0,090$ & 1031,652 & 0,000 \\
12 & $1,614 \pm 0,035$ & $0,327 \pm 0,011$ & $0,214 \pm 0,116$ & 1104,588 & 0,000 \\
16 & $1,656 \pm 0,040$ & $0,332 \pm 0,008$ & $0,215 \pm 0,133$ & 890,347 & 0,000 \\
20 & $1,693 \pm 0,037$ & $0,326 \pm 0,008$ & $0,211 \pm 0,142$ & 849,983 & 0,000 \\
24 & $1,711 \pm 0,049$ & $0,336 \pm 0,009$ & $0,213 \pm 0,153$ & 722,539 & 0,000 \\
28 & $1,579 \pm 0,053$ & $0,319 \pm 0,043$ & $0,207 \pm 0,144$ & 619,587 & 0,000 \\
\hline
\end{tabular}

${ }^{*} \mathrm{O} . \mathrm{D}=600 \mathrm{~nm} \quad \mathrm{SB}=$ simpang baku

Data di atas menunjukkan bahwa pengukuran nilai daya serap cahaya mulai dari 0 jam sampai dengan 28 jam secara statistik menunjukkan perbedaan yang bermakna antara kelompok kontrol dan kelompok perlakuan I dan kelompok perlakuan II. Dikatakan demikian karena semua nilai $p<0,05$ atau dengan kata lain dapat dikatakan bahwa : (a) rerata nilai daya serap cahaya $(O . D=600 \mathrm{~nm})$ pada 0 jam sampai dengan 28 jam kelompok kontrol berbeda bermakna dengan rerata nilai daya serap cahaya pada kelompok perlakuan I; (b) rerata nilai daya serap cahaya $(O . D=600 \mathrm{~nm})$ pada pada 0 jam sampai dengan 28 jam kelompok kontrol berbeda bermakna dengan rerata nilai daya serap cahaya pada kelompok perlakuan II; (c) rerata nilai daya serap cahaya $(O . D=600 \mathrm{~nm})$ pada 0 jam sampai dengan 28 jam kelompok perlakuan I berbeda bermakna dengan rerata nilai daya serap cahaya pada kelompok perlakuan II. Data tersebut disusun dalam kurva pertumbuhan yang menunjukkan perbedaan hambatan pertumbuhan Staphylococcus aureus pada kelompok kontrol, kelompok perlakuan I, dan kelompok perlakuan II. Kurva pertumbuhan Staphylococcus aureus dapat dilihat pada Gambar 1. 


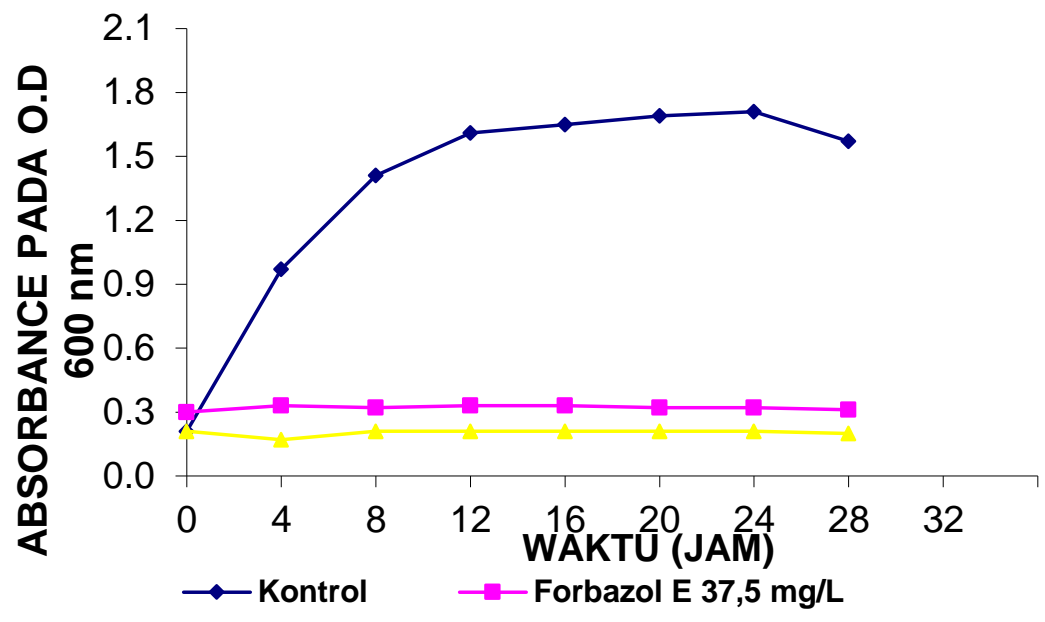

Gambar 1 Kurva Pertumbuhan Staphylococcus aureus pada media Mueller Hinton cair yang diberi perlakuan forbazol E.

\begin{abstract}
Kurva pertumbuhan Staphylococcus aureus di atas menunjukkan bahwa kelompok kontrol mengikuti suatu pola pertumbuhan berupa kurva pertumbuhan sigmoid (kurve normal), perubahan kemiringan pada kurve tersebut menunjukkan transisi dari satu fase perkembangan ke fase lainnya. Kurva pertumbuhan bakteri dapat dipisahkan menjadi empat fase utama : fase lag (fase lamban atau lag phase), fase pertumbuhan eksponensial (fase pertumbuhan cepat atau log phase), fase stasioner (fase statis atau stationary phase) dan fase penurunan
\end{abstract}

populasi (fase kematian atau death phase). Perlakuan I menunjukkan pertumbuhan yang tidak mengikuti suatu pola pertumbuhan kurva sigmoid, begitu pula perlakuan II. Kurva pertumbuhan di atas juga menunjukkan bahwa perlakuan II (forbazol E 75 $\mathrm{mg} / \mathrm{L}) \quad$ menimbulkan hambatan pertumbuhan yang lebih tinggi dibandingkan dengan perlakuan I (forbazol E $37,5 \mathrm{mg} / \mathrm{L}$ ). Analisis bioaktivitas forbazol $\mathrm{E}$ terhadap hambatan pertumbuhan dapat dilihat pada tabel 3

Tabel 3 Hasil uji BNT (Beda Nyata Terkecil) pertumbuhan S.aureus berdasarkan daya serap cahaya

\begin{tabular}{lcc}
\hline \multicolumn{1}{c}{ Kelompok } & Beda rerata nilai daya serap cahaya & Nilai $\mathbf{p}$ \\
\hline 1.Kontrol - Perlakuan I & $1,031^{*}$ & 0,000 \\
2. Kontrol - Perlakuan II & $1,149^{*}$ & 0,000 \\
3. Perlakuan I - Perlakuan II & $0,118^{*}$ & 0,016 \\
\hline$\left.{ }^{*}\right) p<0,05$ & &
\end{tabular}


Hasil analisis di atas menunjukkan bahwa forbazol $E$ dengan konsentrasi 37,5

$\mathrm{mg} / \mathrm{L}$ dan $75 \mathrm{mg} / \mathrm{L}$ dapat menghambat pertumbuhan Staphylococcus aureus secara bermakna karena semua nilai $p$ $<0,05$, akan tetapi dilihat dari beda rerata nilai daya serap cahaya menunjukkan bahwa forbazol $\mathrm{E}$ dengan konsentrasi $75 \mathrm{mg} / \mathrm{L}$ mempunyai daya hambat pertumbuhan yang lebih tinggi daripada forbazol $E$ dengan konsentrasi $37,5 \mathrm{mg} / \mathrm{L}$.

\section{Hambatan Pertumbuhan S.aureus}

Pertumbuhan bakteri dapat dihambat oleh beberapa antimikroba seperti yang telah dilaporkan oleh beberapa peneliti, diantaranya Liu dkk. (2004) menyatakan bahwa pemberian antibiotika penisilin, enoxasin, dan gentamisin pada E.coli pada konsentrasi yang berbeda mempengaruhi pertumbuhan bakteri. Kurve pertumbuhan menunjukkan konsentrasi penisilin $100 \mu \mathrm{g} / \mathrm{ml}$ menyebabkan E.coli mengalami fase stasioner dan akhirnya fase kematian, pada enoxasin konsentrasi $0,4 \mu \mathrm{g} / \mathrm{ml}$ menyebabkan fase stasioner dan akhirnya mengalami fase kematian, sedang gentamisin konsentrasi 0,8 $\mu \mathrm{g} / \mathrm{ml}$ menyebabkan fase stasioner dan fase kematian. Penisilin, gentamisin, enoxasin bersifat bakterisida terhadap E.coli.Temuan Martin dkk. (2003) yang melarutkan karbondioksida pada susu melaporkan bahwa karbondioksida secara signifikan menghambat pertumbuhanbakteri susu pada fase lag, fase eksponensial, dan fase stasioner. Croisier dkk. (2004) melaporkan bahwa gatifloxasin secara signifikan menghambat
Streptococcus pneumoniae. Kurve pertumbuhan menunjukkan gatifloxasin konsentrasi $5 \mathrm{mg} / \mathrm{L}$ menyebabkan fase kematian pada bakteri tersebut.

Forbazol $E$ dalam penelitian ini menunjukkan rerata hambatan pertumbuhan pada Staphylococcus aureus dengan nilai daya serap cahaya adalah 1,357 \pm 0,492 pada kelompok kontrol, 0,325 \pm 0,002 pada kelompok perlakuan I (forbazol E 37,5 mg/L) dan $0,207 \pm 0,109$ pada kelompok perlakuan II ( forbazol E $75 \mathrm{mg} / \mathrm{L}$ ). Hasil analisis ditemukan bahwa hambatan pertumbuhan $S$. aureus antara kelompok kontrol dan perlakuan I serta perlakuan II adalah berbeda bermakna $(p<0,05)$ (tabel 5.1)..

Setiap spesies mempunyai waktu generasi (generation time) untuk melaksanakan pembelahan sel. Staphylococcus aureus mempunyai waktu generasi 20 - 30 menit, selisih waktu 4 jam dalam setiap pengamatan memberikan waktu yang cukup bagi sel untuk melakukan proses pembelahan diri.

Kurva pertumbuhan Staphylococcus aureus (Gambar 1) antara kelompok kontrol dan kelompok perlakuan I serta kelompok perlakuan II yang diukur mulai dari 0 jam sampai dengan 28 jam menunjukkan bahwa hambatan pertumbuhan pada kelompok kontrol, kelompok perlakuan I dan kelompok perlakuan II berbeda bermakna $(p<$ 0,05 ) (tabel 2). Hambatan pertumbuhan Staphylococcus aureus terhadap forbazol $E$ paling tinggi terdapat pada kelompok perlakuan II (forbazol E 75 $\mathrm{mg} / \mathrm{L})$. Hambatan pertumbuhan Staphylococcus aureus terhadap forbazol E pada kelompok perlakuan II (75 mg/L) lebih tinggi dibanding dengan 
kelompok perlakuan I $(37,5) \mathrm{mg} / \mathrm{L}$ (tabel 3.3).

Kelompok kontrol terlihat fase lag dimulai pada 0 jam dengan rerata nilai daya serap cahaya adalah 0,211. Rerata nilai daya serap cahaya pada kelompok perlakuan I (37,5 mg/L) adalah 0,303 . Rerata nilai daya serap cahaya pada kelompok perlakuan II adalah 0,214 (tabel 3.2). Tidak diperoleh nilai daya serap cahaya 0,00 pada 0 jam Karena diperlukan waktu untuk melakukan inokulasi pada tabung reaksi (kontrol, perlakuan I dan perlakuan II) sehingga sel sudah mulai mengalami proses pembelahan diri. Hal ini berarti pada fase log pertambahan populasi berjalan lambat; sel mengalami perubahan dalam komposisi kimiawi dan bertambah ukurannya; substansi intraselular bertambah (Kusnadi dkk., 2003).

Penelitian ini memperlihatkan bahwa pertumbuhan fase log mulai pada 4 jam sampai dengan 12 jam setelah inkubasi. Hasil pengukuran dengan spektrofotometer pada fase log adalah : (1) kelompok kontrol menunjukkan bahwa rerata nilai daya serap cahaya 0,979 pada 4 jam fase log, 1,414 pada 8 jam fase log, dan 1,614 pada 12 jam fase log ; (2) kelompok perlakuan I menunjukkan bahwa rerata nilai daya serap cahaya 0,339 pada 4 jam fase log, 0,323 pada 8 jam fase log, dan 0,327 pada 12 jam fase log ; dan (3) kelompok perlakuan II menunjukkan bahwa rerata nilai daya serap cahaya 0,174 pada 4 jam fase log, 0,212 pada 8 jam fase log, dan 0,214 pada 12 jam fase log (tabel 5.2). Hasil ini menunjukkan bahwa forbazol $E$ secara bermakna menghambat pertumbuhan sel Staphylococcus aureus dengan $p<0,05$.

Hasil pengukuran dengan spektrofotometer pada fase stasioner adalah: (1) kelompok kontrol menunjukkan bahwa rerata nilai daya serap cahaya adalah 1,656 pada 16 jam fase stasioner, 1,693 pada 20 jam fase stasioner, dan 1,711 pada 24 jam fase stasioner; (2) kelompok perlakuan I menunjukkan bahwa rerata nilai daya serap cahaya 0,332 pada 16 jam fase stasioner, 0,326 pada 20 jam fase stasioner, dan 0,336 pada 24 jam fase stasioner; dan (3) kelompok perlakuan II menunjukkan bahwa rerata nilai daya serap cahaya 0,215 pada 16 jam fase stasioner, 0,211 pada 20 jam fase stasioner, dan 0,213 pada 24 jam fase stasioner (tabel 5.2). Hal ini berarti pada fase stasioner terjadi penumpukan produk beracun atau kehabisan nutrien; beberapa sel mengalami kematian; jumlah sel hidup menjadi tetap (Kusnadi, dkk., 2003).

Fase penurunan populasi atau fase kematian atau death phase terjadi pada saat medium kehabisan nutrien maka populasi bakteri akan menurun jumlahnya. Pada penelitian ini ditemukan bahwa fase penurunan populasi terjadi pada 28 jam setelah inkubasi. Hasil analisis menunjukkan bahwa kelompok kontrol rerata nilai daya serap cahaya adalah 1,579, kelompok perlakuan I adalah 0,319, dan kelompok perlakuan II adalah 0,207. Hal ini berarti pada fase penurunan populasi, sel yang mengalami kematian lebih cepat daripada terbentuknya selsel baru; laju kematian mengalami percepatan secara eksponensial; bergantung pada spesiesnya, semua sel 
mengalami kematian dalam waktu beberapa hari (Brock dkk., 2003).

Hasil penelitian ini menunjukkan, pertumbuhan pada kelompok kontrol (tanpa forbazol E) mengalami fase-fase seperti yang dijelaskan Brock dkk.(2003) yaitu fase lag, fase log, fase penurunan populasi dan fase kematian mengikuti suatu pola pertumbuhan berupa kurva pertumbuhan sigmoid. Pada kelompok perlakuan I (forbazol E $37,5 \mathrm{mg} / \mathrm{L}$ ) terlihat fase lag, fase log, fase stasioner, fase penurunan populasi atau fase kematian yang hampir sama yaitu mendatar, ini menunjukkan bahwa forbazol $E$ mempunyai kemampuan untuk menghambat pertumbuhan Staphylococcus aureus dengan merusak secara struktural dinding sel mikroba tersebut. Kelompok perlakuan II (forbazol E $75 \mathrm{mg} / \mathrm{L}$ ) memperlihatkan fase lag, fase log, fase stasioner, fase penurunan populasi atau fase kematian yang hampir sama yaitu mendatar. Kurva pertumbuhan yang mendatar (Gambar 1) pada perlakuan I maupun perlakuan II kemungkinan disebabkan karena forbazol $\mathrm{E}$ memiliki lima pusat aktif yaitu : $\mathrm{Cl}, \mathrm{NH}, \mathrm{N}, \mathrm{O}$ dan $\mathrm{OH}$, yang dapat membentuk ikatan hidrogen dengan bagian peptida substrat. Hal ini memungkinkan forbazol $E$ berinteraksi dengan bagian peptida lewat ikatan hidrogen dan menghalangi terjadinya reaksi pembentukan ikatan amida, sehingga biosintesis dinding sel terhalang. Mekanisme ini, mungkin menyebabkan kerusakan dinding sel Staphylococcus aureus setelah pemberian forbazol $E$ baik pada kelompok perlakuan I $(37,5 \mathrm{mg} / \mathrm{L})$ dan kelompok perlakuan II (75 mg/L), namun hal ini perlu penelitian lebih lanjut.
Hambatan pertumbuhan oleh forbazol E pada perlakuan II lebih tinggi daripada perlakuan I. Hal ini disebabkan karena konsentrasi forbazol $E$ yang digunakan dalam kelompok perlakuan II dinaikkan dua kali lipat daripada perlakuan I. Ini menunjukkan bahwa forbazol $E$ pada konsentrasi $75 \mathrm{mg} / \mathrm{L}$ mempunyai hambatan pertumbuhan lebih tinggi dibanding dengan konsentrasi $37,5 \mathrm{mg} / \mathrm{L}$ pada $S$. aureus .

Hasil analisis juga menunjukkan bahwa hambatan pertumbuhan pada kelompok perlakuan II berbeda bermakna dengan kelompok perlakuan I $(p<0,05)$ (tabel 5.3). Dengan demikian dapat dikatakan bahwa kelompok perlakuan II (forbazol E dengan konsentrasi $75 \mathrm{mg} / \mathrm{L})$ menimbulkan hambatan pertumbuhan yang lebih tingggi dibandingkan dengan kelompok perlakuan I (forbazol $\mathrm{E}$ dengan konsentrasi $37,5 \mathrm{mg} / \mathrm{L})$. Gambar 5.1 memperlihatkan kurva pertumbuhan Staphylococcus aureus yang diukur dengan spektrofotometer mulai dari 0 jam sampai 28 jam.

Pertumbuhan

merupakan peningkatan seluruh unsur pokok kimia sel. Hal tersebut merupakan suatu proses yang memerlukan replikasi seluruh struktur, organel, dan komponen protoplasma seluler dengan adanya nutrien dalam lingkungan sekelilingnya. Dalam pertumbuhan bakteri, semua substansi essensial harus tersedia untuk sintesis dan pemeliharaan protoplasma, dengan sumber energi, dan kondisi lingkungan yang sesuai.

Bakteri sebagai suatu kelompok merupakan organisme yang memperlihatkan kemampuan yang sangat besar dalam menggunakan bahan makanan yang tersebar, 
menyusun bahan anorganik menjadi senyawa organik yang sangat kompleks.Beberapa spesies juga tumbuh pada berbagai relung ekologik dengan temperatur, keasaman, dan tekanan oksigen yang ekstrim.Kemampuan bakteri untuk bertahan di bawah keadaan sekitar yang demikian merupakan perlindungan dari adaptabilitas tinggi dan refleks kapasitasnya dalam keberhasilan merespon suatu stimulus yang dianggap asing atau tidak pernah ditemuinya.

\section{SIMPULAN}

Berdasarkan hasil penelitian
dan pembahasan maka dapat disimpulkan sebagai berikut: (1) Forbazol $E$ dalam menghambat pertumbuhan Staphylococcus aureus (2) Forbazol E pada konsentrasi $75 \mathrm{mg} / \mathrm{L}$ menimbulkan hambatan pertumbuhan Staphylococcus aureus lebih tinggi dibandingkan dengan pada konsentrasi $37,5 \mathrm{mg} / \mathrm{L}$.

Berdasarkan simpulan di atas dapat digunakan sebagai acuan dalam menyampaikan saran sebagai berikut. (1) Diperlukan penelitian lebih lanjut mengenai mekanisme secara fungsional terjadinya hambatan pertumbuhan Staphylococcus aureus oleh forbazol E (2) Diperlukan penelitian lebih lanjut untuk mengetahui konsentrasi optimum forbazol $E$ dalam menghambat

pertumbuhan Staphylococcus aureus, yang berguna dalam penelitian klinis dengan menggunakan hewan percobaan.

\section{DAFTAR PUSTAKA}

Bawa, W. 2000.Rancangan Penelitian Eksperimental Di Bidang Biologi dan Pendidikan Biolog.Seminar PSP.Biologi.Singaraja : PMIPA STKIP

Brock, T. D., Madigan, M. T., Martinko, J. 2003.Biology of Microorganisms.New York : Prentice Hall .

Ichiba,T.Y., Scheuer,W.Y., Higa, P.J., Gravalos,D.G.1991.Hennoxazole $\mathrm{s}$ : BioactiveBisoxazoles from MarineSponge.

J.Am.Chem.Soc.113 : 31733178

Jawetz, E., Melnick, J., Adelberg, E. 2004. Medical Microbiology. Third edition. New York: Published by Appleton \& Lange.

Kusnadi, Peristiwati, Syulasmi, A., Purwianingsih, Rochintaniawati, D. 2003.

Mikrobiologi.Jakarta : Techinical Cooperation Project for Development ofScience and Mathematics Teaching for Primary and Secondary Education inlndonesia (IMSTEP).

Lavangelde, P.V., Ravensbergen, E., Grashoff, P., Beckhuizen, H., Groeneveld, P.H.P., Dissel, J.V.V. 1999. Antibiotic-Induced Cell wall fragments of S.aureusincrease Endothelial chemokine secretion and adhesiveness for granulocytes. Antimicrobial Agents and Chemotherapy. 43 (12) : 2984-2989.

Leid, J. G., Shirtliff, M. E. , Costerton, J.W., Stoodley, P. 2002. Human Leukocyt Adhere to,Penetrate, and respond to Staphylococcus aureus Biofilms. Infection and Immunity. 70 (11) : 6339-6345. 
Lindquist, N., Fenical, W., Van Duyne, G.D., Clardy,J. 1991. Isolation and Structure Determination of Diazonamides $A$ and $B$, Usual Cytotoxic metabolites from Marine Ascidian Diazona sinensis J.Am.Chem.Soc.113 : 2303-2310.

Liu, Y.Q., Zhang, Y.Z., Gao, P.J. 2004. Novel Consentration-Killing Curve MethodFor Estimation of Bactericidal Potency of Antibiotics in an In Vitro Dynamic

Model.Antimicrobial Agents and Chemotherapy.48 : 3884-3891. (Diakses 7 September 2006).

Martin, J.D., Werner, B.G., Hotchkiss, J.H. 2003.Effects of Carbon Dioxide on Bacterial Growth Parameters in Milk as Measured by Conductivity.Journalof Dairy Science.86 : 1932-1940. (Diakses 8 Agustus 2006).

Matsunaga, S., Fujiki, H., Sakata,D., Fusetani. 1991. Calyculins E,F,G and $\mathrm{H}$, Additional Inhibitor of Protein 1 and 2A. from the marine Sponge Discodermia calyx. Tetrahedron.47 : 4393-4400.

Mckee, T., Mckee, J. R. 2003.Biochemistry.Boston McGraw-Hill.

Mims,C., Dockrell, H.M., Goering, R.V., Roitt, I., Wakelin,D., Zuckerman, M. 2004.

Medical Microbiology.Third Edition. New York: Mosby.

Moat, A.G., Foster, J.W., Spector,M.P.2002. Microbial Physiology.fourth edition. New York : Wiley-Liss.

Muderawan, I .W. 2003.Laporan Riset Unggulan Terpadu VIII Bidang IImu Kimiadan Proses. Sintesis dan Uji Bioaktivitas Forbazol dan Turunannya. Kementrian

Riset dan Teknologi RI.Lembaga IImu Pengetahuan Indonesia.

Paget, S. D.2003.Synthesis and Antibacterial Activity of pyrroloarylsubstitutedOxazolidinones.Biorg anic \& Medicinal Chemistry Letters. $13:$ 4173-4177.

Pelczar, M.J.Jr.,Chan, E.C.S.1993. Microbiology: Consepts and Applications.New York: McGrawHill Inc.

Radspieler, A, Liebscher, J. 2001.Synthesis of Chlorooxazoles related to NaturalProducts.Synthesis.5 : 745-750.

Radspieler, A. 2000. Untersuchungen zur Synthese von Diazonamid A undPhorbazol A Und C (dissertation). HumboldtUniversitat zu Berlin.

Ristiati, N.P. 2005. Laporan DIKS Bidang Penelitian Murni.Aktivitas Bakterisida

Forbazol E Terhadap Pertumbuhan Staphylococcus aureus. IKIP Negeri Singaraja.

Rochiman, K. 1989. Dasar Perancangan Percobaan dan Rancangan Acak Lengkap.Surabaya : Universitas Airlangga.

Rohde, H., Knobloch, J. K.M., Horstkotte, M.A., Mack, D. 2001. Correlation of

Staphylococcus aureusicaADBC Genotype and Biofilm

Expresssion

Phenotype.Journal of Clinical Microbiology. Vol.39.

No.12.p.4595-4596. 
Sastroasmoro, S., Ismail, S. 2002. Dasar-dasar MetodologiKlinis. Edisi ke 2Jakarta : CV Sagung Seto.

Soediro, I. 2000. Bahan Alam Hayati Bahari, Perkembangan dan Prospeknya dalamBidang Farmasi. Dalam Pengetahuan Alam dan Pengembangannya, Jakarta : Dirjen Dikti Depdikbud.
Shopsin, B., Kreiswirth, B.N. 2001.Molecular Epidemiology of Methicilin-Resistant Staphylococcus aureus.(Diakses 1 Agustus 2001).http://medscape.com./gov $\mathrm{mt} / \mathrm{CDC} / \mathrm{EID} / 2001 / \mathrm{v} 07$.

Walsh, C. 2000.Molecular Mechanisms that confer antibacterial drug resistence.Nature.406 : 678-685. 